Jurnal KIBASP (Kajian Bahasa, Sastra dan Pengajaran)

Volume 1, No 1, Desember 2017

e-ISSN : 2597-5218

p-ISSN : 2597-520X

DOI: https://doi.org/10.31539/kibasp.v1i1.95

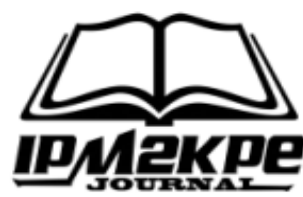

\title{
PENGARUH MODEL PEMBELAJARAN COOPERATIVE INTEGRATED \\ READING AND COMPOSITION (CIRC) TERHADAP KEMAMPUAN \\ MENULIS PROPOSAL SISWA KELAS XI MA. MAZRO'ILLAH KOTA LUBUKLINGGAU
}

\author{
Muhtadin \\ Program Studi Pendidikan Bahasa dan Sastra Indonesia, STKIP-PGRI Lubuklinggau \\ muhtadinstkip@gmail.com
}

Submit, 08-12-2017 Accepted,31-12-2017 Publish,31-12-2017

\begin{abstract}
ABSTRAK
Penelitian ini bertujuan untuk mengetahui ada atau tidaknya pengaruh model pembelajaran Cooperative Integrated Reading and Composition (CIRC) terhadap Kemampuan Menulis Proposal Siswa Kelas XI MA.Mazro'illah Lubuklinggau. Metode penelitian ini adalah menggunakan metode eksperimen dengan rancangan berbentuk pretest-postest control group design atau desain kelompok kontrol eksperimen. Populasi dalam penelitian ini adalah seluruh siswa kelas XI MA.Mazro'illah Lubuklinggau Tahun Pelajaran 2017/2018. Dua kelas diambil sebagai sampel secara simple random sampling yaitu kelas XI.IPA sebagai kelas eksperimen dan kelas XI.IPS sebagai kelas kontrol. Teknik pengumpulan data menggunakan teknik tes tertulis. Data tes kemampuan siswa dianalisis dengan menggunakan uji-t. Berdasarkan hasil analisis uji-t, dengan taraf kepercayaan $\square=0,05$ dan derajat kebebasan $(\mathrm{dk})=41$, didapat thitung > ttabel (4,06 > 2,02), maka H0 ditolak dan Ha diterima. Dengan demikian hipotesis berbunyi ada pengaruh model pembelajaran Cooperative Integrated Reading and Composition (CIRC) terhadap Kemampuan Menulis Proposal Siswa Kelas XI MA. Mazro'illah Lubuklinggau dapat diterima kebenarannya, dengan nilai rata-rata kelas eksperimen 80,14 lebih besar dari kelas kontrol 69,38.
\end{abstract}

Kata Kunci: Model Cooperative Integrated Reading and Composition (CIRC), Kemampuan Menulis Proposal.

\section{ABSTRACT}

This study aims to determine whether or not the influence of Cooperative Integrated Reading and Composition (CIRC) learning model on Writing Skill of Student Proposal of Grade XI MA.Mazro'illah Lubuklinggau. The method of this research is using experimental method with pretest-posttest control group design design or experimental control group design. The population in this research is all students of class XI MA.Mazro'illah Lubuklinggau Lesson Year 2017/2018. Two classes were taken as simple random sampling samples of class XI.IPA as experimental class and class XI.IPS as control class. Data collection techniques use written test techniques. Student ability test data were analyzed by using $t$ test. Based on the result of $t$-test analysis, with the level of trust $0,05=\square$ and degrees of freedom $(\mathrm{dk})=41$, obtained tcount $>t$-table (4.06> 2.02), then $\mathrm{HO}$ is rejected and Ha accepted. Thus the hypothesis reads that there 
is an influence of Cooperative Integrated Reading and Composition (CIRC) learning model to the Writing Skill of Student Proposal of Class XI MA.Mazro'illah Lubuklinggau is acceptable truth, with the average value of experimental class 80,14 is biggerthancontrolclass69,38.

Keywords: Cooperative Integrated Reading and Composition (CIRC) Model, Writing Capability Proposal

\section{PENDAHULUAN}

Masalah Pendidikan merupakan sarana dan wahana yang sangat baik di dalam pembinaan sumber daya manusia. Pendidikan memiliki peranan yang penting dalam upaya mengembangkan dan mewujudkan potensi yang dimiliki siswa. Menurut Rusman (2010) "Pengembangan potensi tersebut bisa dimulai dengan menumbuhkan keterampilan dan kemampuan berpikir kritis, kreatif, logis, sistematis, argumentatif dan lain-lain".

Kemampuan-kemampuan berpikir merupakan sesuatu yang perlu dimiliki oleh siswa, sebagai bekal untuk menghadapi persoalan-persoalan yang akan dihadapi, baik persoalan yang ada di sekolah maupun persoalan yang ada di kehidupan sehari-hari. Di samping itu, kemajuan teknologi yang terus meningkat dan berkurangnya persediaan sumber-sumber alam menambah persoalan hidup menjadi semakin kompleks. Oleh karena itu, untuk mengatasi hal tersebut dituntut kemampuan adaptasi secara kreatif untuk mencari pemecahan yang imajinatif.

Sekolah merupakan suatu lembaga yang berperan sebagai tempat berlangsungnya kegiatan belajar dan pembelajaran secara sadar dan terencana, untuk mengembangkan dan mewujudkan sosok peserta didik yang memiliki kepribadian, kecerdasan, pengendalian diri, serta keterampilan yang diperlukanya dalam masyarakat (Trianto, 2010).

Pengajaran bahasa Indonesia di sekolah memiliki peran, kedudukan dan fungsi yang sangat penting sebagai sarana untuk melatih keterampilan siswa dalam menggunakan bahasa untuk kegiatan sehari-hari, baik secara lisan maupun tertulis. Hal ini sesuai dengan kurikulum Bahasa dan Sastra Indonesia (2006) menyatakan bahwa pengajaran Bahasa dan Sastra Indonesia meliputi empat komponen yaitu, penguasaan kebahasaan, mengapresiasi sastra, kemampuan memahami dan kemampuan menggunakan bahasa. 
Berbicara tentang bahasa tidak terlepas dari membicarakan tentang empat keterampilan berbahasa, seperti yang dikemukakan Tarigan (2008) terampil berbahasa artinya terampil menyimak (listening skill), berbicara (speaking skill), membaca (reading skill), dan menulis (writing skill). Keempat keterampilan tersebut berkaitan dengan bahasa sebagai sarana komunikasi manusia.

Untuk mencapai tujuan pengajaran bahasa Indonesia guru harus benarbenar menyadari bahwa dalam proses pembelajaran bahasa Indonesia pada dasarnya melatih siswa agar memiliki keterampilan berbahasa dengan baik dan siswa harus terampil menggunakan bahasa Indonesia sebagai alat komunikasi, baik dalam keterampilan menyimak, berbicara, membaca, dan menulis (Hakim, 2007). Hal ini juga diperlukan agar siswa dapat meningkatkan kemampuan memahami materi yang disampaikan oleh guru.

Menurut Endraswara (2005) "Kemampuan adalah kesanggupan atau kecakapan seseorang atau kelompok dalam melakukan suatu kegiatan yang berhubungan dengan jasmani dan rohani”. Salah satu pembelajaran kemampuan menulis yang dipelajari siswa kelas XI MA.Mazro'illah Lubuklinggau adalah menulis proposal. Berdasarkan hasil observasi peneliti terhadap kemampuan menulis proposal siswa kelas XI MA Mazro'illah Lubuklinggau masih rendah, hal tersebut diketahui dari tes kemampuan menulis proposal di kelas XI belum mencapai Kriteria Ketuntasan Minimum (KKM) sebesar 75. Jumlah siswa kelas XI 90 siswa, namun yang tuntas hanya 43 siswa $(47,78 \%)$ sedangkan 47 siswa lainnya belum tuntas. Masih rendahnya kemampuan siswa menulis proposal disebabkan kurangnya minat siswa terhadap materi dan model pembelajaran yang digunakan oleh guru cenderung kurang bervariasi.

Guru sebagai kreator dan motivator dalam kegiatan pembelajaran berkewajiban untuk menciptakan lingkungan belajar yang kreatif bagi peserta didiknya. Salah satu kegiatan yang dapat dilakukan oleh guru adalah dengan memilih dan menentukan model pembelajaran yang tepat yang bukan hanya memberikan materi ajar secara teoritis saja.

Pemberian materi ajar secara teoretis tidak akan ada artinya, tanpa didukung dengan kemampuan guru memilih dan menerapkan model pembelajaran yang bervariasi. Materi pelajaran akan mudah dimengerti jika diaplikasikan dengan menggunakan model pembelajaran yang tepat. Selain itu, guru juga harus profesional dan kreatif. Seperti yang dikemukakan Rusman (2010) "Guru dituntut untuk 
melaksanakan proses belajar mengajar yang menggunakan berbagai macam metodemetode yang disesuaikan dengan pokok pembahasan".

Salah satu upaya untuk mencapai tujuan belajar menulis proposal, peneliti menggunakan model pembelajaran Cooperative Integrated Reading and Composition (CIRC). Model pembelajaran Cooperative Integrated Reading and Composition merupakan model pembelajaran Cooperative, yang menekankan belajar kelompok heterogen saling membantu satu sama lain, bekerja sama menyelesaikan suatu masalah. Hal tersebut sejalan yang diungkapkan oleh Suyatno (2009) bahwa "Model pembelajaran cooperative adalah kegiatan pembelajaran dengan cara berkelompok untuk bekerja sama saling membantu mengkonstruksi konsep, menyelesaikan persoalan atau inkuiri".

Pada model pembelajaran Cooperative Integrated Reading and Composition, siswa diajak berpartisipasi dalam kegiatan belajar mengajar, siswa akan dikelompokan secara heterogen oleh guru 4-5 orang perkelompok untuk berdiskusi mengenai materi yang telah dijelaskan oleh guru. Model pembelajaran Cooperative Integrated Reading and Composition digunakan dalam penelitian ini sebagai alternatif dalam penyampaian materi menulis proposal, untuk mencapai tujuan pembelajaran dan diharapkan dapat mengatasi kendala yang dihadapi oleh guru dalam membelajarkan menulis proposal. Atas dasar inilah peneliti tertarik untuk melakukan penelitian dengan judul "Pengaruh Model Pembelajaran Cooperative Integrated Reading and Composition (CIRC) terhadap Kemampuan Menulis Proposal Siswa Kelas XI MA. Mazro'illah Lubuklinggau"

\section{METODE PENELITIAN}

Metode penelitian ini adalah menggunakan metode eksperimen. Menurut Arikunto (2010), metode eksperimen adalah suatu cara untuk mencari hubungan sebab akibat (hubungan klausal) antara dua faktor yang sengaja ditimbulkan oleh peneliti dengan cara mengeliminasi atau mengurangi faktor-faktor lain yang mengganggu. Pada penelitian ini menggunakan rancangan berbentuk pretest-postest control group design atau desain kelompok kontrol eksperimen. Dalam penelitian ini, model Cooperative Integrated Reading And Composition (CIRC) sebagai kelompok eksperimen dan pembelajaran dengan metode konvensional sebagai kelompok kontrol. Rancangan penelitian dapat ditunjukan pada pola berikut ini: 


$$
\frac{\mathrm{E} \mathrm{O}_{1} \times \mathrm{O}_{2}}{\mathrm{~K} \mathrm{O}_{3} \mathrm{X} \mathrm{O}_{4}}
$$

Keterangan:

$$
\begin{array}{ll}
\mathrm{E} & : \text { Kelas eksperimen } \\
\mathrm{K} & : \text { Kelas kontrol } \\
\mathrm{O}_{1} \text { dan } \mathrm{O}_{3} & : \text { Tes yang dilakukan sebelum eksperimen } \\
\mathrm{X} & : \text { Treatment atau perlakuan } \\
\mathrm{O}_{2} \text { dan } \mathrm{O}_{4} & : \text { Tes yang dilakukan setelah eksperimen. }
\end{array}
$$

Dalam penelitian ini terdapat dua variabel yang digunakan yaitu variabel bebas dan variabel terikat. Variabel bebas dalam penelitian ini adalah model 30 pembelajaran Cooperative Integrated Reading And Composition (CIRC). Variabel terikat dalam penelitian ini adalah kemampuan siswa menulis proposal. Populasi yang diambil dalam penelitian ini adalah seluruh siswa kelas XI MA.Mazro'illah Lubuklinggau Tahun Pelajaran 2017/2018 sebanyak 90 Siswa, dengan Teknik pengambilan sampel secara simple random sampling karena pada teknik sampel random atau acak peneliti mencampurkan subjeksubjek di dalam populasi yang mana setiap kelas dari seluruh subjek memiliki kesempatan yang sama untuk dipilih sebagai sampel.

Pengambilan sampel acak sederhana yang dapat dilakukan dengan cara undian, memilih dari daftar bilangan secara acak. Menurut Sugiyono (2011) langkah-langkah dalam pengambilan sampel simple random sampling, yaitu sebagai berikut:

1. Menetapkan nomor kelas masing-masing yaitu kelas XI. IPA 1 nomor satu, kelas XI.IPA 2 nomor 2, dan seterusnya.

2. Mengundi nomor urut yang telah ditulis pada kertas kecil kemudian digulung;

3. Menetapkan kelas yang terpilih menjadi sampel yaitu kelas XI.IPA 2 sebagai kelompok eksperimen dan XI.IPA 1 sebagai kelompok kontrol.

Teknik pengumpulan data yang akan dilaksanakan adalah teknis tes. Teknik tes dalam penelitian ini adalah penulis menggunakan tes tertulis. Tujuan tes tertulis tersebut untuk mengukur kemampuan siswa dalam menulis proposal siswa kelas XI MA.Mazro'illah Lubuklinggau dengan kriteria sebagai berikut : 
Tabel 1

Item-item Penilain Proposal

\begin{tabular}{|c|c|c|c|c|}
\hline No & Unsur yang Dinilai & Rubrik Penilaian & Skor & $\begin{array}{c}\text { Skor } \\
\text { Maksimal }\end{array}$ \\
\hline 1 & Judul & $\begin{array}{l}\text { Penentuan nama kegiatan/ judul Proposal : } \\
\begin{array}{l}\text { a. Tepat } \\
\text { b. Cukup Tepat } \\
\text { c. Kurang Tepat }\end{array}\end{array}$ & $\begin{array}{l}5 \\
3 \\
1\end{array}$ & 5 \\
\hline \multirow[t]{2}{*}{2} & Isi Proposal & $\begin{array}{l}\text { Kesesuaian dengan unsur-unsur proposal : } \\
\begin{aligned} \text { a. } & \text { Baik } \\
\text { b. } & \text { Cukup Baik } \\
\text { c. } & \text { Kurang Baik }\end{aligned}\end{array}$ & $\begin{array}{l}50 \\
25 \\
10\end{array}$ & 50 \\
\hline & & $\begin{array}{l}\text { Kesesuaian isi dengan tujuan proposal : } \\
\begin{aligned} \text { a. } & \text { Baik } \\
\text { b. } & \text { Cukup Baik } \\
\text { c. } & \text { Kurang Baik }\end{aligned}\end{array}$ & $\begin{array}{r}10 \\
7 \\
5\end{array}$ & 10 \\
\hline \multirow[t]{4}{*}{3} & Tata penulisan proposal & $\begin{array}{l}\text { Penggunaan bahasa yang tepat: } \\
\text { a. Tepat } \\
\text { b. Cukup tepat } \\
\text { c. Kurang tepat }\end{array}$ & $\begin{array}{l}10 \\
7 \\
5\end{array}$ & 10 \\
\hline & & $\begin{array}{l}\text { Menghindari kalimat panjang dan bertele- } \\
\text { tele: } \\
\text { a. Baik } \\
\text { b. Cukup Baik } \\
\text { c. Kurang Baik }\end{array}$ & $\begin{array}{l}5 \\
3 \\
1\end{array}$ & 5 \\
\hline & & $\begin{array}{l}\text { Penggunaan paragraf yang tepat } \\
\text { a. Tepat } \\
\text { b. Cukup tepat } \\
\text { c. Kurang tepat }\end{array}$ & $\begin{array}{r}10 \\
7 \\
5\end{array}$ & 10 \\
\hline & Jumlah & & & 100 \\
\hline
\end{tabular}

\section{HASIL PENELITIAN}

Hasil Penelitian Penelitian ini dilaksanakan di MA .Mazro'illah Lubuklinggau dengan menggunakan dua kelas sampel yaitu kelas eksperimen dan kelas kontrol. Pada kelas eksperimen yaitu XI.IPA.2 proses pembelajaran menggunakan model Cooperative Integrated Reading and Composition (CIRC) sedangkan pada kelas kontrol yaitu kelas XI.IPA.1 menggunakan model konvensional. Pada pelaksanaan pembelajaran peneliti bertindak sebagai pengajar. Pelaksanaan pre-test kelas eksperimen dan kelas kontrol diikuti oleh semua siswa. Data hasil post-test diperoleh setelah dua kelas mendapat perlakuan yang berbeda dalam pembelajaran bahasa indonesia pada materi menulis proposal.

Data tersebut untuk menentukan perbedaan hasil belajar antara dua kelas. Pada penelitian ini jumlah pertemuan tatap muka yang dilakukan adalah sebanyak lima kali pertemuan, satu kali pemberian pre-test, dua kali proses pembelajaran, dan satu kali post-test yang dilaksanakan pada tanggal 16 Sepetember 2017 sampai dengan 26 
Oktober 2017. Sebelum dilaksanakan pembelajaran di kelas terlebih dahulu dilaksanakan pre-test yang berfungsi untuk mengetahui kemampuan awal siswa dalam menulis proposal. Pada pelaksanaan pre-test kelas eksperimen diikuti oleh semua siswa yaitu 22 orang dan kelas kontrol juga diikuti oleh semua siswa yaitu 21 siswa. Setelah dilakukan pre-test kemudian peneliti melaksanakan pembelajaran dengan perlakuan yang berbeda pada kedua kelas tersebut, kemudian dilakukan posttest untuk menentukan perbedaan hasil belajar kedua kelas.

\section{PEMBAHASAN}

Berdasarkan hasil penelitian tersebut, diketahui bahwa hasil tes kemampuan menulis proposal siswa sebelum menggunakan model pembelajaran Cooperative Integrated Reading and Composition (CIRC) diperoleh nilai rata-rata 56,32 dari jumlah 22 siswa, dengan predikat kurang.

Sedangkan hasil tes Kemampuan Menulis Proposal siswa setelah menggunakan model pembelajaran Cooperative Cooperative Integrated Reading and Composition (CIRC) diperoleh nilai rata-rata 80,14 dengan predikat baik dari jumlah 22 siswa. Jika dilihat dari uraian di atas terdapat selisih nilai pretes dan postes. Diketahui nilai hasil tes kemampuan menulis proposal siswa sebelum menggunakan model pembelajaran Cooperative Integrated Reading and Composition (CIRC) lebih rendah jika dibandingkan dengan hasil tes kemampuan menulis proposal siswa setelah menggunakan model pembelajaran Cooperative Integrated Reading And Composition (CIRC). Hal ini disebabkan sedikitnya ide-ide siswa muncul dalam menulis proposal sehingga hasil belajar siswa menjadi kurang baik dalam pelajaran menulis proposal.

Sedangkan dengan menggunakan model Cooperative Integrated Reading and Composition (CIRC), ternyata mampu memunculkan ide-ide siswa dalam mengikuti proses belajar mengajar dengan aktif dan menyenangkan, karena kegiatan pembelajaran diarahkan pada membaca dan menulis, sehingga siswa harus banyak membaca atau menuangkan gagasannya dalam bentuk tulisan. Dengan menggunakan model Cooperative Integrated Reading and Composition (CIRC) siswa dapat menuangkan ide atau gagasan yang terdapat dalam pikirannya ke dalam keterampilan menulis secara runtun. Semua gagasan yang disampaikan dengan menggunakan bahasa yang komunikatif. 
Pretes dilaksanakan dengan cara memberi tugas kepada siswa untuk menulis proposal baik kelas eksperimen maupun kelas kontrol. Hasil pretes menulis proposal adalah sebagai berikut: nilai siswa pada kelas kontrol dengan nilai baik tidak ada, yang mendapatkan nilai cukup ada 6 orang, sedangkan yang mendapatkan nilai kurang ada 14 orang, dan sebanyak 1 orang yang mendapat nilai gagal. Sedangkan pada kelas eksperimen siswa yang mendapatkan nilai baik tidak ada, ada 7 orang yang mendapatkan nilai cukup, 14 orang yang mendapatkan nilai kurang, dan 1 orang yang memiliki nilai gagal.

Kemudian untuk nilai postes tingkat kemampuan nilai siswa pada kelas kontrol sebanyak 1 orang mendapatkan nilai baik sekali, 7 siswa mendapat nilai baik, 11 orang yang mendapatkan nilai cukup dan 2 siswa mendapat nilai kurang. Sedangkan pada kelas eksperimen siswa yang mendapatkan nilai baik sekali sebanyak 7 orang, kemudian ada 11 orang yang mendapatkan nilai baik, 4 orang yang mendapatkan nilai cukup dan yang mendapatkan nilai kurang atau gagal tidak ada.

Berdasarkan analisis data pos-test terdapat perbedaan hasil belajar antara kelas eksperimen dan kelas kontrol menulis proposal mendapat peningkatan. Ini disebabkan oleh perlakuan yang diberikan pada kelas eksperimen yang diajarkan dengan menggunakan model Cooperative Integrated Reading and Composition (CIRC) memperoleh rata-rata 80,14 sedangkan pada kelas kontrol dengan model konvensional memperoleh ratarata sebesar 69,38.

Dengan demikian rata-rata hasil pos-test kelas eksperimen lebih tinggi dari pada dengan kelas kontrol. Jika hasil post-test dibandingkan pre-test, maka terjadi peningkatan hasil belajar setelah mengikuti kegiatan pembelajaran. Nilai rata-rata pretest kelas eksperimen adalah 56,32 sedangkan nilai rata-rata post-test 80,14. Berarti terjadi peningkatan rata-rata nilai sebesar 23,82. Nilai rata-rata ( $x$ ) pre-test pada kelas kontrol adalah 55,24, sedangkan nilai rata-rata ( x ) posttest adalah 69,38. Hal ini berarti terjadi peningkatan rata-rata sebesar 14,14 . Artinya peningkatan nilai rata-rata kelas eksperimen lebih tinggi dibandingkan dengan kelas kontrol.

Terjadinya peningkatan nilai rata-rata ini dikarenakan pengaruh dari perlakuan dari model Cooperative Integrated Reading and Composition (CIRC). Hal ini dilihat dari hasil wawancara yang menunjukkan bahwa minat siswa terlihat sangat besar terhadap materi pelajaran menulis proposal dan siswa lebih aktif dan suasana pembelajaran menjadi lebih menyenangkan. Selain itu hasil analisis data penelitian 
menggunakan uji-t, dengan taraf kepercayaan $0,05=\square$ dan derajat kebebasan $(\mathrm{dk})=61$, didapat thitung > ttabel $(4,06>2,02)$, maka H0 ditolak dan Ha diterima. Dengan demikian hipotesis berbunyi: "Ada pengaruh model pembelajaran Cooperative Integrated Reading and Composition (CIRC) terhadap Kemampuan Menulis Proposal Siswa Kelas XI MA.Mazro'illah Lubuklinggau”, dengan rata-rata skor nilai $\geq 75$ dapat diterima kebenarannya. Walaupun rata-rata kemampuan siswa terjadi peningkatan namun masih terdapat siswa yang belum mampu mencapai standar nilai sudah ditentukan. Hal ini dikarenakan keterbatasan waktu peneliti dalam menjelaskan materi menulis proposal menggunakan model Cooperative Integrated Reading and Composition (CIRC) dan juga terbatasnya referensi tentang menulis proposal

\section{SIMPULAN}

Berdasarkan hasil penelitian dan pembahasan, diperoleh kesimpulan bahwa dari hasil analisis uji-t, dengan taraf kepercayaan $0,05=\square$ dan derajat kebebasan $(\mathrm{dk})=40$, didapat thitung > ttabel $(4,06>2,02)$, maka H0 ditolak dan Ha diterima. Dengan demikian hipotesis berbunyi: "ada pengaruh model Cooperative Integrated Reading and Composition (CIRC) terhadap kemampuan menulis proposal siswa kelas XI MA.Mazro'illah Lubuklinggau dapat diterima kebenarannya", yang dilihat dari nilai rata-rata kelas eksperimen 80,14 lebih besar dari kelas kontrol 69,38. 


\section{DAFTAR PUSTAKA}

Arikunto, Suharsimi. (2010). Prosedur Penelitian Suatu Pendekatan Praktik Edisi Revisi Jakarta : Rineka Cipta.

Endraswara. (2005). Kemampuan Dasar Menulis. Jakarta: Universitas Terbuka.

Hakim. (2007). Panduan Menulis Dasar. Malang: UMM Pres.

Rusman, (2010). Seri Manajemen Sekolah Bermutu Model-Model Pembelajaran Mengembangkan Profesionalisme Guru. Jakarta: Rajawali Pers.

Sugiyono. (2011). Metode Penelitian Pendidikan Penelitian Kuantitatif, Kualitatif, dan $R \& D$. Bandung: Alpabeta.

Suyatno. (2009). Menjelejah Seratus Pembelajaran Inovatif. Sidoharjo: Masmedia Buana Pustaka.

Tarigan, Henry, Guntur. (2008). Berbicara Sebagai Suatau Keterampilan Berbahasa. Bandung: Angkasa Bandung.

Trianto. (2010). Mendesain Model Pembelajaran Inovatif-Progresif. Jakarta: Prenada Media. 